\title{
Peningkatan Kemampuan Pemecahan Masalah Aljabar Siswa SMP Melalui Pembelajaran Modul Aljabar Berbasis Relational Thinking
}

\author{
Darsono $^{1}$, Ika Santia ${ }^{2}$, Jatmiko ${ }^{3}$ \\ ${ }^{1,2,3}$ Program Studi Pendidikan Matematika, FKIP, Universitas Nusantara PGRI Kediri \\ Jl. Veteran No. 76 Kediri , Jawa Timur, Indonesia \\ e-mail : darsono@unpkediri.ac.id , telp +6281252654859
}

Article received : 07 Agustus 2018, article revised : 27 Februari 2018, article published: 20 Maret 2018

\begin{abstract}
Abstrak
Kemampuan berpikir relasional merupakan bagian yang penting dari pembelajaran matematika sekolah. Pada materi persamaan aljabar, siswa mengalami kesulitan dalam menyelesaikan masalah tersebut karena kurangnya pemahaman simbol relasi ekuivalensi. Hal ini menunjukkan bahwa pemecahan masalah selama ini hanya menuntut siswa mengaplikasikan algoritma untuk mendapatkan jawaban akhir, tidak mendukung siswa untuk berpikir dan menemukan sendiri konsep relasi ekuivalensi. Oleh karena itu dikembangkan suatu media pembelajaran aljabar yang merangsang kemampuan berpikir relasional siswa SMP dengan harapan akan mendukung kemampuan pemecahan masalah aljabar siswa SMP. Untuk itu, penelitian ini bertujuan menganalisis ada tidaknya peningkatan pemecahan masalah aljabar siswa SMP setelah menggunakan modul aljabar berbasis berpikir relasional. Penelitian ini merupakan jenis penelitian eksperimen dengan pendekatan kuantitatif yang menggunakan uji-t dua sampel berpasangan untuk menganalisis peningkatan kemampuan pemecahan masalah. Teknik pengumpulan data dalam penelitian ini menggunakan tes tulis relasi. Sampel yang digunakan adalah siswa kelas VII sebanyak 30 siswa. Data dianalisis dengan bantuan Program SPSS 21. Hasil penelitian menunjukkan terjadi peningkatan kemampuan pemecahan masalah aljabar setelah penggunaan modul aljabar berbasis berpikir relasional dengan sig $=0,00<5 \%$ dengan $\mathrm{t}$ hitung $=-6,43>-\mathrm{t}_{0,05}$. Jadi penggunaan modul dapat meningkatkan kemampuan pemecahan masalah aljabar siswa SMP.
\end{abstract}

Kata kunci: Pemecahan masalah; Aljabar; Modul; Berpikir Relasional

\section{Enhancing Ability of Problem Solving Algebra Students SMP Through Learning Relational Thinking Algebra Based Module}

\begin{abstract}
The relational thinking ability is an important part of mathematics school learning. In the material of algebraic equations, students have difficulty in solving the problem because they lack of understanding of equivalence relation symbols. This showed that problem solving only requires to apply the algorithm to get the final answer, not to support students to think and find themselves the concept of equivalence relation. Therefore developed learning media of algebra that stimulates the relational thinking skills of Junior High School students in hopes will support the ability of solving algebra problems of Junior High School students. Therefore, this study aims to analyze the increase ability in solving algebra problems of junior high school students after using relational based algebra module. This research is a descriptive research with quantitative approach which uses two paired samples t-test to analyze the improvement of problem solving ability. Technique of collecting data in this research using write test relation. The sample used is the students of class VII of 30 students. The data were analyzed with the help of SPSS 21 Program. The results showed an increase in algebra problem solving ability after the use of relational thinking algebra based module with sig $=0,00<5 \%$ with $t$ arithmetic $=-6,43>-t_{0,05}$. So the use of module can improve the problem solving ability of Junior High School students in algebra.
\end{abstract}

Key Words: Problem solving; Algebra; Module; Relational Thinking 


\section{PENDAHULUAN}

Proses berpikir merupakan suatu hal yang penting dalam pembelajaran matematika. Hal ini didukung oleh Depdiknas (2006) yang menyatakan bahwa melalui pembelajaran matematika, siswa diharapkan memiliki kemampuan berpikir logis, analitis, sistematis, kritis, dan kreatif, serta memiliki kemampuan bekerja sama. Tetapi pada kenyataannya, pentingnya proses berpikir ini tidak didukung oleh praktek pembelajaran matematika di sekolah. Pembelajaran matematika di sekolah selama ini difokuskan menghitung jawaban. Hal ini terlihat dari observasi yang dilakukan Santia (2016) kemampuan berpikir komputasi masih diperlihatkan 16 siswa dari 20 siswa kelas 7 di SMP di Kota Kediri. Berpikir komputasi inilah yang membuat siswa hanya terpaut pada pemahaman prosedural. Dalam observasi tersebut, ketika siswa diberikan masalah $\frac{1}{1+x}=2$ maka salah satu siswa dengan kemampuan komputasional menjawab $1=2(1+x)$ sehingga didapatkan nilai $x=-\frac{1}{2}$, sedangkan siswa dengan pola pikir relasional cenderung melihat relasi antara kedua ruas. Siswa berpikir bahwa 2 berelasi dengan $\frac{1}{\frac{1}{2}}$ sehingga didapatkan $1+x=\frac{1}{2}$ dan nilai $x=-\frac{1}{2}$.

Pentingnya berpikir relasional ini dimiliki siswa menurut Napaphun (2012) adalah karena berpikir relasional merupakan kemampuan untuk memahami analogi antara objek atau peristiwa yang tampaknya berbeda dan menerapkan aturan abstrak dalam situasi baru. Dengan demikian berpikir relasional merupakan proses mental yang ditandai dengan membangun keterkaitan diantara unsur-unsur informasi yang diberikan dengan pengetahuan yang dimiliki sebelumnya maupun pengetahuan tentang sifat-sifat atau struktur matematika untuk menyelesaikan masalah matematika. Melalui pemberdayaan proses berpikir relasional ini, diharapkan dapat meningkatkan kemampuan pemecahan masalah persamaan relasi aljabar siswa.

Stephens (2006) menyatakan bahwa berpikir relasional bergantung pada kemampuan siswa mengidentifikasi fleksibilitas dan menggunakan berbagai kemungkinan variasi antara bilangan dalam masalah bilangan. Hal ini memungkinkan siswa akan mempertimbangkan ekspresi kedua sisi tanda sama, dan menggunakan relasi antara ekspresi tanpa perlu menghitung. Untuk memastikan berpikir relasional dikembangkan pendukung melalui intruksi yang memberikan kesempatan bagi siswa untuk mengintegrasikan penalaran aritmetika dan aljabar. Sedangkan Baiduri (2011) menyatakan bahwa siswa dikatakan berpikir relasional jika : 1) Siswa melihat tanda sama dengan sebagai simbol relasi, 2) Siswa dapat fokus ada struktur ekspresi dan 3) siswa dapat memberikan rasionalitas penggunaan strategi untuk menyelesaikan masalah kalimat bilangan yang melibatkan operasi. Ini berarti siswa yang menyelesaikan permasalahan dengan menggunakan pemikiran relasional memanfaatkan pemahaman bilangan mereka untuk mempertimbangkan ekspresi aritmetika dari perspektif struktural bukan sekedar prosedural. Bila menggunakan berpikir relasional, kalimat-kalimat yang ada dianggap sebagi keseluruhan, bukan sebagai proses untuk mengerjakan langkah demi langkah.

Berdasarkan pendapat di atas berpikir relasional adalah proses mental yang ditandai dengan membangun relasi antara unsur-unsur informasi yang diberikan dengan pengetahuan yang dimiliki sebelumnya maupun pengetahuan tentang sifat-sifat atau struktur matematika untuk menyelesaikan masalah matematika. Oleh karena itu indikator berpikir relasional yang digunakan dalam penelitian ini adalah: 
Tabel 1. Rubrik Penyekoran Berpikir Relasional

\begin{tabular}{cl}
\hline Skor & \multicolumn{1}{c}{ Indikator } \\
\hline 0 & - Dapat membuktikan semua persamaan aritmatika melalui bukti perhitungan prosedural \\
& - Hanya dapat menunjukkan hasil akhir tanpa menyebutkan metode yang digunakan \\
\hline 1 & $\begin{array}{l}\text { Terlihat adanya metode berpikir relasional tapi tidak dieksekusi dengan benar sehingga } \\
\text { mendapat jawaban akhir yang benar }\end{array}$ \\
\hline 2 & Berpikir relasional jelas ditunjukkan dalam satu pernyataan dan dieksekusi dengan benar \\
\hline 3 & $\begin{array}{l}\text { Berpikir relasional jelas ditunjukkan dalam dua pertanyaan tetapi salah satunya dipecahkan } \\
\text { dengan pemikiran relasional yang salah }\end{array}$ \\
\hline 4 & $\begin{array}{l}\text { Semua masalah dipecahkan dengan jelas dan benar menggunakan pemikiran relasional dan } \\
\text { solusi persamaan secara komputasional juga diberikan secara paralel }\end{array}$ \\
\hline
\end{tabular}

Diadaptasi dari Sthephens (2006)

\section{METODE}

\section{Sampel Penelitian}

Penelitian ini menggunakan pendekatan kuantitatif komparasional, yaitu penelitian yang membandingkan hasil tes awal dan tes akhir setelah pembelajaran menggunakan modul berpikir relasional. Subjek uji coba meliputi siswa kelas VII SMP dari dua sekolah yaitu SMP PGRI Kota Kediri dan SMP Islam Al Ikhlas Tarokan Kabupaten Kediri yang keseluruhan berjumlah 30 siswa, 18 siswa dari SMP PGRI (sekolah 1) dan 12 siswa dari SMP Islam Al Ikhlas Tarokan (sekolah 2). Teknik sampling yang digunakan adalah random sampling dan penelitian tersebut dilaksanakan pada bulan Mei 2017.

\section{Instrumen Penelitian}

Dalam penelitian ini terdapat empat ins-trumen penelitian yang digunakan, yaitu: 1) lembar angket validasi, 3) tes tulis relasi aljabar, dan 3) lembar angket respon siswa. Lembar validasi diberikan kepada ahli materi, ahli bahasa dan satu ahli grafis. Angket tertutup atau angket validasi oleh para ahli dianalisis secara deskriptif kuantitatif. Persentase tersebut diperoleh dengan berdasarkan perhitungan skor menurut Skala Likert (Khabibah, 2006) dengan keterangan skala penilaian untuk validasi ahli yaitu "5" bernilai sangat baik, "4" bernilai baik, "3" bernilai cukup baik, "2" bernilai tidak baik, dan " 1 " bernilai sangat tidak baik. Adapun untuk item penilaian lembar telaah materi dan validasi dikembangkan berdasarkan kriteria penilaian modul yang baik yaitu self instructional, self contained, stand alone, adaptive, used friendly dan consistent (Anwar, 2010).

Lembar angket tertutup mengenai respon siswa dianalisis secara deskriptif kuantitatif. Persentase tersebut diperoleh berdasarkan perhitungan Skala Guttman (Khabibah, 2006) dengan keterangan skala penilaian untuk pendapat siswa yaitu "Ya" dengan nilai satu dan "Tidak" dengan nilai nol. Dari hasil analisis angket respon siswa dapat dilakukan penarikan kesimpulan bahwa modul dianggap layak untuk digunakan bila interpretasinya $\geq 61 \%$. Kemudian hasil perhitungan nilai dari ahli materi, ahli grafis, ahli bahasa dan respon siswa diitepretasikan ke dalam kategori sebagai berikut:

Tabel 2. Intepretasi Kelayakan Modul

\begin{tabular}{cc}
\hline Penilaian & Kriteria Intepretasi \\
\hline $0 \%-20 \%$ & Sangat Tidak Layak \\
\hline $21 \%-40 \%$ & Tidak Layak \\
\hline $41 \%-60 \%$ & Cukup Layak \\
\hline $61 \%-80 \%$ & Layak \\
\hline $81 \%-100 \%$ & Sangat Layak \\
\hline
\end{tabular}

Berdasarkan kriteria tersebut, Lembar Kegiatan Siswa dalam penelitian ini dikatakan layak apabila persentase $\geq 61 \%$.

Sedangkan untuk tes tulis relasi aljabar awal dan akhir akan digunakan untuk mengukur tingkat pemecahan masalah aljabar siswa dengan didasarkan pada tahap pemecahan masalah Polya yang meliputi perumusan masalah, perencanaan masalah, pelaksanaan rencana penyelesaian masalah dan memeriksa kembali penyelesaian yang telah dilakukan. 


\section{Teknik Analisis Data}

Uji statistik yang digunakan adalah uji dua sampel berpasangan dengan hipotesis komparatif .Uji-t digunakan untuk menguji dua sampel yang berpasangan (satu sampel dengan uji awal melalui pretes dan uji akhir melalui post tes), dan dilihat apakah mempunyai rata-rata berbeda atau tidak. Ukuran sampel yang digunakan $n<30$. Assumsi yang harus dipenuhi data harus berdistribusi normal. Adapun untuk penelitian ini uji tersebut dihitung dengan menggunakan program SPSS versi 21.

\section{Menafsirkan Hasil Uji t-paired samples test}

\section{Paired sample statistic}

Menunjukkan mean hasil belajar matematika siswa sebelum diberi pelakuan adalah .... dan sesudah diberi perlakuan adalah ..... Sampel yang dianalisis $\mathrm{n}=$.....Standar deviasi sebelum dan sesudah perlakuan adalah ...dan...

\section{Paired sample correlation}

Menunjukkan korelasi kemampuan pemecahan masalah siswa sebelum dan sesuda diberi pelakuan modul berbasis relasional thinking adalah ....Nilai koefisien ini menunjukkan hubungan yang sangat erat dan pada kolom sig=....berarti hubungan tersebut nyata atau signifikan.

\section{Paired sample test.}

Adapun hipotesis dalam penelitian ini adalah:

Ho: Tidak ada perbedaan kemampuan pemecahan masalah aljabar siswa sebelum dan sesudah diberi pelakuan modul aljabar berbasis relasional thinking.

$\mathbf{H}_{1}$ : Ada perbedaan kemampuan pemecahan masalah aljabar siswa sebelum dan sesudah diberi pelakuan modul aljabar berbasis relasional thinking.

\section{Hasil Paired sample test}

Menunjukkan sig $=\ldots$ karena nilai $\operatorname{sig}=\ldots<$ $\alpha=5 \%$ maka Ho ditolak. Jadi H1 diterima sehingga ada perbedaan kemampuan pemecahan masalah aljabar siswa sebelum dan sesudah diberi pelakuan modul aljabar berbasis relasional thinking.

\section{HASIL DAN PEMBAHASAN}

\section{Hasil}

Adapun data yang diperoleh setelah penelitian adalah sebagai mana tertera pada tabel 3 :

Tabel 3. Hasil Revisi Modul oleh Para Ahli

\begin{tabular}{cccccccccccc}
\hline $\begin{array}{c}\text { Siswa } \\
\text { ke- }\end{array}$ & $\begin{array}{c}\text { Seko- } \\
\text { lah }\end{array}$ & $\begin{array}{c}\text { Nilai } \\
\text { pretes }\end{array}$ & $\begin{array}{c}\text { Nilai } \\
\text { postes }\end{array}$ & $\begin{array}{c}\text { Siswa } \\
\text { ke- }\end{array}$ & $\begin{array}{c}\text { Seko- } \\
\text { lah }\end{array}$ & $\begin{array}{c}\text { Nilai } \\
\text { pretes }\end{array}$ & $\begin{array}{c}\text { Nilai } \\
\text { postes }\end{array}$ & $\begin{array}{c}\text { Siswa } \\
\text { ke- }\end{array}$ & $\begin{array}{c}\text { Seko- } \\
\text { lah }\end{array}$ & $\begin{array}{c}\text { Nilai } \\
\text { pretes }\end{array}$ & $\begin{array}{c}\text { Nilai } \\
\text { postes }\end{array}$ \\
\hline 1 & 1 & 65 & 70 & 11 & 1 & 70 & 75 & 21 & 1 & 52 & 67 \\
\hline 2 & 2 & 73 & 75 & 12 & 2 & 65 & 70 & 22 & 2 & 49 & 60 \\
\hline 3 & 1 & 81 & 85 & 13 & 1 & 63 & 70 & 23 & 1 & 82 & 85 \\
\hline 4 & 2 & 64 & 70 & 14 & 2 & 78 & 80 & 24 & 2 & 90 & 90 \\
\hline 5 & 1 & 80 & 85 & 15 & 1 & 80 & 80 & 25 & 1 & 84 & 85 \\
\hline 6 & 2 & 57 & 68 & 16 & 2 & 75 & 80 & 26 & 1 & 67 & 78 \\
\hline 7 & 1 & 64 & 72 & 17 & 1 & 68 & 72 & 27 & 1 & 86 & 88 \\
\hline 8 & 2 & 73 & 78 & 18 & 2 & 45 & 50 & 28 & 1 & 59 & 76 \\
\hline 9 & 1 & 86 & 90 & 19 & 1 & 86 & 88 & 29 & 1 & 59 & 75 \\
\hline 10 & 2 & 91 & 92 & 20 & 2 & 92 & 95 & 30 & 1 & 67 & 87 \\
\hline & & & & & & & & Sumber $:$ hasil pretes dan postes
\end{tabular}

Setelah diperolah data pretes dan postes tersebut maka dilakukan analisis data meng- gunakan SPSS 21 sehingga menghasilkan analisis sebagai mana tertera pada tabel 4 : 
JIPM (Jurnal Ilmiah Pendidikan Matematika), 6(2), Maret 2018-123

Darsono, Ika Santia, Jatmiko

Tabel 4. Hasil Tes Normalitas Data

Tests of Normality

\begin{tabular}{|c|r|r|r|r|r|r|r|}
\hline & \multicolumn{9}{|l|}{ Kolmogorov-Smirnov $^{\text {a }}$} & \multicolumn{2}{l|}{ Shapiro-Wilk } & \\
\cline { 2 - 8 } & Statistic & df & Sig. & Statistic & df & Sig. & \\
\hline awal &, 108 & 30 &, $200^{*}$ &, 967 & 30 & &, 470 \\
akhir &, 127 & 30 &, $200^{*}$ &, 962 & 30 & &, 343 \\
\hline
\end{tabular}

*. This is a lower bound of the true significance.

a. Lilliefors Significance Correction

Dari tabel 4 didapatkan data berdistribusi normal dikarenakan nilai pretes dengan signifikansi 5\% adalah 0,470>0,05 begitu juga untuk nilai postes dengan signifikasi $5 \%$ adalah $0,343>0,05$

Dikarenakan data berdistribusi normal makan dapat dilakukan uji selanjutnya yaitu uji 2 sampel berpasangan.

Tabel 5. Hasil Uji Dua Sampel Berpasangan

Paired Samples Test

\begin{tabular}{|c|c|c|c|c|c|c|c|c|c|}
\hline & & \multicolumn{5}{|c|}{ Paired Differences } & \multirow[t]{3}{*}{$\mathrm{T}$} & \multirow[t]{3}{*}{$\mathrm{df}$} & \multirow{3}{*}{$\begin{array}{l}\text { Sig. } \\
(2- \\
\text { tailed })\end{array}$} \\
\hline & & \multirow[t]{2}{*}{ Mean } & \multirow[t]{2}{*}{$\begin{array}{l}\text { Std. } \\
\text { Deviati } \\
\text { on }\end{array}$} & \multirow[t]{2}{*}{$\begin{array}{l}\text { Std. } \\
\text { Error } \\
\text { Mean }\end{array}$} & \multicolumn{2}{|c|}{$\begin{array}{l}95 \% \\
\text { Confidence } \\
\text { Interval of the } \\
\text { Difference }\end{array}$} & & & \\
\hline & & & & & Lower & Upper & & & \\
\hline Pair 1 & awal - akhir & $-6,167$ & 5,253 & ,959 & $-8,128$ & $-4,205$ & $-6,430$ & 29 & , 000 \\
\hline
\end{tabular}

Dari hasil yang terlihat pada tabel di atas nilai signifikasinya $0,000<0,05$, oleh karena itu dapat dikatakan bahwa ada perbedaan kemampuan pemecahan masalah siswa sebelum dan sesudah diberi pelakuan modul berbasis relasional thinking.

\section{Pembahasan}

Untuk mengetahui respon siswa terhadap modul yang dikembangkan ditinjau dari kriteria kesesuaian dengan komponen berpikir relasional pada soal-soal latihan, penyajian fisik, dan bahasa. Keseluruhan analisis hasil ujicoba terbatas modul menghasilkan 82 siswa mendapat skor berpikir relasional tinggi dan diperoleh rata-rata persentase respon sebesar $87,51 \%$, maka pengembangan modul pembelajaran aljabar yang didasarkan pada kemampuan berpikir relasional dinya-takan
"Sangat Layak". Hal tersebut dikarena-kan pembelajaran dengan modul tersebut dapat membantu siswa dalam berpikir relasional.

Hasil tersebut sesuai dengan pernyataan Baiduri (2015) bahwa siswa dapat memberikan rasionalitas penggunaan strategi untuk menyelesaikan masalah.

\section{SIMPULAN}

Berdasarkan hasil penelitian, dapat diambil simpulan bahwa pengembangan modul berdasarkan kemampuan berpikir relasional, meliputi: terdapat peningkatan kemampuan pemecahan masalah aljabar siswa SMP setelah menggunakan modul aljabar berbasis berpikir relasional. Sehingga untuk penelitian selanjutnya dapat dianalisis lebih lanjut faktorfaktor lain yang terkait dengan berpikir relasional.

\section{DAFTAR PUSTAKA}

Anwar, Ilham. (2010) Pengembangan Bahan Ajar. Bahan Kuliah Online. Direktori UPI. Bandung.

Baiduri (2011) Profil Berpikir Relasional Siswa SD Menyelesaikan Masalah Matematika ditinjau dari Kemampuan 
Matematika dan Gender. Disertasi tidak dipublikasikan. UNESA Surabaya.

Baiduri. (2015). Mathematics education students' understanding of equal sign and equivalent equation. Asian Social Science, 11(25), 15-24. https://doi.org/10.5539/ass.v11n25p15

Depdiknas (2006) Kurikulum Tingkat satuan Pendidikan. Jakarta: Pusat Kurikulum, Balitbangdiknas, Jakarta.

Depdiknas (2013) Kurikulum 2013. Jakarta: Pusat Kurikulum, Balitbangdiknas, Jakarta. Khabibah, Siti. (2006) Pengembangan Model Pembelajaran Matematika Dengan Soal Terbuka Untuk Meningkatkan Kreativitas Siswa Sekolah Dasar. Disertasi yang tidak dipublikasikan. UNESA Surabaya.
Muslich, Masnur. (2010) Text Book Writing. Yogyakarta: Ar-Ruzz Media

Napaphun, V. (2012). Relational Thinking: Learning Arithmetic in order to Promote Algebraic Thinking. Journal of Science and Mathematics, 35(2), 84-101.

Sadiman, dkk. (2012) Media Pendidikan. Jakarta: Rajagrafindo Persada

Solso, Robert L. (1995) Cognitive Psychology. Boston. Allyn and Bacon

Sugiyono (2010) Memahamai Penelitian Kualitatif. Bandung: CV.ALFABETA

Thiagarajan and Semmel \& Semmel. (1974) Instructional Development for Training Teachers of Exceptional Children. Bloomington: Indiana University 